Ethos: Jurnal Penelitian dan Pengabdian kepada Masyarakat, Vol 8, No.2, Juni 2020: 221-228

\title{
Program SANATA (Sayang Anak Balita) di Wilayah Posyandu RW 08 SRONDOL KULON
}

\section{${ }^{1}$ Rachma Purwanti, ${ }^{2}$ Eka Cahyaningsih, ${ }^{3}$ M.Rifky Al Haedar, ${ }^{4}$ Noviasti Rahma Utami, ${ }^{5}$ Werry Lisfani, ${ }^{6}$ Nur Hidayah}

\author{
1,2,3,4,5,6 Universitas Diponegoro, Semarang, Jawa Tengah, Indonesia \\ email:1'rachmapurwanti@fk.undip.ac.id
}

\begin{abstract}
Prevalence of malnutrition among under five years old children still high. Results of nutrition problem analyzed among under five years old children at RT 01, 02, and $03 R W 08$ Srondol, Semarang City showed that overweight and stunting proportions among under five years old children were still high. This community nutrition program had objective to optimized Integrated service post (POSYANDU) function to monitor growth and development of under-five years old children $(D / S)$ with contribution of stakeholder, increasing maternal knowledge about complementary feeding and feeding practice for children, increasing feeding practice for under-five children, and increasing nutritional status $(W / H)$ of under-five years old children. These community service programs were being held in December 2018 with community relation methods. This program involved stakeholders, POSYANDU cadre, and mother of overweight and stunting children at RW 08 Srondol Kulon, Banyumanik District, Semarang City. The result of "SANATA: sayang anak balita" includes : 1) there was the participation of local government for programs, increasing of POSYANDU participation $(D / S)$ from $32,5 \%$ - 37,1\%. There was an increased in mother knowledge and feeding practice. Nutritional intake of under five years old children increased and get 80-110\% sufficiency for macronutrient. None children had decreased on $W / H$ nutritional status and increasing of nutritional status $(W / H)$ occur on 5 from 10 stunting children. We hoped that there was a sustainability of the program with knowledge updating for mothers. Reward from RW/posyandu for mother with normal nutritional status of children, haved good nutritional knowledge, and had the capability to child feeding practice would give support from them to optimized nutritional status.
\end{abstract}

Keywords: nutritional status, overweight, stunting, improving nutrition

\begin{abstract}
Abstrak. Prevalensi masalah gizi buruk, gizi kurang, stunting, dan gizi lebih pada balita masih cukup tinggi. Hasil analisis masalah gizi pada balita di RT 01, 02, dan 03 RW 08 Srondol, Kota Semarang yaitu masih tingginya proporsi status gizi lebih dan status gizi pendek (stunting) pada balita. Program pengabdian kepada masyarakat ini bertujuan untuk mengoptimalkan fungsi posyandu dalam pemantauan tumbuh kembang anak (cakupan D/S) dengan melibatkan stakeholder terkait, meningkatkan pengetahuan ibu tentang MP-ASI dan pemberian makan pada balita, meningkatkan pola asuh ibu balita dalam pemberian makan balita sesuai kebutuhan, dan meningkatkan status gizi BB/TB pada balita. Program pengabdian kepada masyarakat ini dilaksanakan pada bulan Desember Tahun 2018 dengan metode community relation. Program melibatkan tokoh masyarakat, kader posyandu, dan ibu balita berstatus gizi lebih dan gizi pendek di wilayah RT 01, 02 dan $03 R W 08$ Kelurahan Srondol Kulon Kecamatan Banyumanik, Kota Semarang. Hasil dari program SANATA: sayang anak balita ini adalah adanya partisipasi tokoh masyarakat dalam program, meningkatnya angka partisipasi posyandu (cakupan D/S) di Posyandu Mawar RW 08 yaitu dari 32,5 \% menjadi 37,1 \%. Terdapat peningkatan pengetahuan ibu tentang MP-ASI dan pemberian makan pada balita. Asupan zat gizi pada balita yang dilihat dari perubahan pola makan balita dapat mencapai kecukupan 80-110\% zat gizi makro. Tidak terjadi penurunan status gizi $B B / T B$ (pada 10 balita) dan terjadi peningkatan status gizi BB/TB pada 5 dari 10
\end{abstract}


balita stunting. Diharapkan adanya upaya menjaga keberlanjutan program dengan pengkayaan materi (update pengetahuan) pada ibu balita secara berkala. Penghargaan/reward/apresiasi dari pihak RW/posyandu bagi ibu yang memiliki balita berstatus gizi baik, memiliki pengetahuan gizi yang baik, serta mampu melaksanakan pola pengasuhan dan pemberian makan yang baik bagi balita akan lebih menyemangati para ibu balita dalam mengoptimalkan gizi balitanya.

Kata Kunci: gizi balita, gizi lebih, stunting, perbaikan gizi

\section{Pendahuluan}

Masalah gizi pada usia bawah lima tahun (balita) masih menjadi pokok perhatian bidang gizi masyarakat. Hal tersebut dikarenakan prevalensi masalah gizi buruk, gizi kurang, stunting, dan gizi lebih masih cukup tinggi. Proporsi balita gizi buruk dan gizi kurang secara nasional menurut hasil Riset Kesehatan Dasar (Riskesdas) 2018 sebesar 17,7\% padahal target RPJMN 2019 sebesar 17\%. Proporsi status gizi sangat pendek dan pendek pada balita berdasarkan Riskesdas 2018 juga masih tergolong tinggi yaitu sebesar 30,8\% (11,5\% sangat pendek dan $19,3 \%$ pendek). Adapun proporsi status gizi sangat kurus, kurus, dan gemuk pada balita berturutturut sebesar 3,5\%, 6,7\%, dan 8,0\%.(Kementerian Kesehatan, 2018)

Berdasarkan hasil identifikasi melalui observasi di posyandu "Mawar" RW 08 RT 01, 02 dan 03 Kelurahan Srondol Kulon Kecamatan Banyumanik, Kota Semarang, terdapat masalah gizi pada balita yaitu status gizi lebih, status gizi kurang, dan status gizi pendek (stunting). Dengan cukup banyaknya masalah gizi yang ada, maka dilakukan analisis prioritas masalah agar dapat menentukan masalah mana yang mudah ataupun lebih penting untuk ditangani segera. Penetapan prioritas masalah dari sekian banyaknya masalah gizi yang ada dilakukan dengan metode CARL (Capability, Assessibility, Readiness, dan Leverage). Metode CARL ini merupakan teknik atau cara yang digunakan untuk menentukan prioritas masalah dengan menentukan skor atas kriteria tertentu seperti kemampuan (Capability) kemampuan dilihat dari sumber daya, dana, alat dan sebagainya. Kemudian kemudahan (accessibility) masalah yang ada mudah diatas atau tidak dan juga dapat didasarkan pada ketersediaan metode/cara/ teknologi serta penunjang seperti peraturan. Readines yaitu kesiapan dari tenaga pelaksana maupun kesiapan sasaram, seperti keahlian atau kemampuan. Dan Leverage yaitu seberapa besar pengaruh kriteria yang satu dengan lain dalam pemecahan masalah yang dibahas. Penggunaan metode CARL ini dikarenakan dengan cukup banyaknya masalah yang ada, dapat menentukan peringkat atas masing- masing masalah sehingga dapat diperoleh prioritas masalah. Dari hasil analisis ini diperoleh prioritas masalah gizi pada balita di RW 08 RT 01, 02, dan 03 yaitu status gizi lebih dan status gizi pendek (stunting) pada balita. Status gizi pendek (stunting) pada balita juga menjadi prioritas karena prevalensi pendek di RW 08 (RT 01,02 dan 03) Srondol Kulon mencapai 33,3 \% dari total 30 balita yang disurvei.

$$
\text { Masalah gizi terutama }
$$

stunting/pendek pada sangat berhubungan dengan prestasi pendidikan yang buruk. Anak-anak stunting berisiko tinggi untuk tumbuh menjadi orang dewasa yang kurang pendidikan, miskin, kurang sehat dan lebih rentan terhadap penyakit tidak menular.(UNICEF et al., 2018) Penelitian menunjukkan bahwa stunting dipengaruhi oleh berbagai determinan yang sangat kompleks. 
Determinan utama yaitu karena kurangnya asupan zat gizi, penyakit infeksi kronis, dan penyakit parasit pada usus.(Bhutta et al., 2008) Faktor lain yang merupakan prediktor stunting yaitu tidak ASI eksklusif, rendahnya sosioekonomi keluarga, bayi lahir prematur, berat bayi lahir rendah, panjang badan lahir rendah, ketidaksesuaian dalam pemberian makanan pendamping ASI, kelompok usia 25-59 bulan, pendidikan ibu, dan tinggi badan ibu. (Abeway et al., 2018; Tumilowicz et al., 2018)

Permasalahan status gizi lebih dan status gizi pendek (stunting) pada balita juga berkaitan dengan keberadaan Pos Pelayanan Terpadu (Posyandu) dan penggeraknya yaitu kader posyandu. Pos Pelayanan Terpadu (Posyandu) berperan dalam menyebarluaskan informasi kesehatan dan menyediakan pelayanan kesehatan dasar, terutama berkaitan dengan kesehatan ibu dan anak.(Kementerian kesehatan, 2011) Termasuk pula masalah gizi dan status gizi pada anak. Selain itu, berdasarkan penelitian diketahui bahwa kredibilitas kader posyandu berpengaruh terhadap partisipasi masyarakat pada program kesehatan.(Dewi \& Anisa, 2018) Posyandu dan kader posyandu berkaitan erat dengan optimalisasi status gizi dan pemantauan tumbuh kembang balita. Program ini bertujuan untuk :

1. Mengoptimalkan fungsi posyandu dalam pemantauan tumbuh kembang anak (cakupan D/S) dengan melibatkan stakeholder terkait (memberikan dukungan dan membantu menyebarluaskan informasi terkait jadwal posyandu).

2. Meningkatkan pengetahuan ibu tentang MP-ASI dan pemberian makan pada balita.

3. Meningkatkan pola asuh ibu balita dalam pemberian makan balita sesuai kebutuhan.
4. Mengoptimalkan asupan zat gizi pada balita yang dilihat dari perubahan pola makan balita dapat mencapai kecukupan 80$110 \%$ zat gizi makro.

5. Meningkatkan status gizi $\mathrm{BB} / \mathrm{TB}$ pada 5 anak.

\section{Metode}

Program SANATA: sayang anak balita ini dilaksanakan di Kelurahan Srondol Kulon, Kecamatan Banyumanik, Kota Semarang. Program dilaksanakan selama bulan Desember Tahun 2018. Metode pelaksanaan program adalah community relation. Program melibatkan tokoh masyarakat, kader posyandu, dan ibu balita berstatus gizi lebih dan gizi pendek di wilayah RW 08 RT 01, 02 dan 03 Kelurahan Srondol Kulon Kecamatan Banyumanik, Kota Semarang. Program dilaksanakan melalui 4 kegiatan yaitu :

1. Advokasi dan bina suasana yang dilakukan melibatkan tokoh masyarakat.

Yaitu ketua kader posyandu, ketua RW serta ketua RT 1, 2 dan 3 dan tokoh agama. Advokasi dan bina suasana secara umum bertujuan untuk mendapatkan perijinan terkait program yang akan dilaksanakan serta mendapat dukungan dan partisipasi dari tokoh masyarakat dan pihak terkait untuk membantu program gizi pada balita serta mendapatkan dukungan pelaksanaan posyandu. Dukungan yang diharapakan yaitu berupa ajakan serta himbauan tokoh masyarakat kepada warga untuk mengikuti posyandu, memberikan informasi pelaksanaan posyandu, dan manfaat posyandu dalam pemantauan pertumbuhan dan perkembangan balita.

2. Sosialisasi Posyandu

Sosialisasi ditujukan kepada warga RW 08, terutama untuk ibu yang memiliki balita. Materi yang dipaparkan yaitu mengenai pentingnya pelaksanaan posyandu, keuntungan mengikuti 
kegiatan posyandu, kerugian jika tidak mengikuti kegiatan posyandu, dan jadwal pelaksanaan posyandu di RW 08 . Sosialisasi dilakukan dengan menggunakan media berupa MMT.

\section{Edukasi}

Proses edukasi gizi dilakukan kepada ibu/pengasuh balita berstatus gizi lebih dan gizi pendek (stunting), dengan cara door to door agar intervensi yang diberikan tepat sasaran. Informasi yang diberikan antara lain yaitu mengenai pemilihan bahan makanan yang tepat dan bervariasi yang disesuaikan dengan kondisi keluarga dan kandungan gizinya cukup. Setelah penyampaian edukasi, dilakukan tanya jawab mengenai materi maupun hal lain yang berkaitan.

\section{Konseling}

Konseling dilakukan kepada ibu maupun pengasuh dari balita yang berstatus gizi lebih dan gizi pendek (stunting). Proses konseling diawali dengan pemaparan masalah yang dialami oleh balita. Selama proses konseling diperlukan komunikasi dua arah antara konselor dan klien untuk membantu mencari alternatif penyelesaian masalah, memberikan motivasi untuk memperbaiki pola asupan makan balita. Proses konseling dilakukan dengan menggunakan media booklet.

\section{Hasil dan Pembahasan}

Peserta program pengabdian SANATA: sayang anak balita ini terdiri dari ibu balita, khususnya yang berstatus gizi lebih dan stunting, Peserta berasal dari Berikut pencapaian dari program SANATA: sayang anak balita:

1. Advokasi dan bina suasana

Advokasi dan bina suasana dilakukan dengan sasaran beberapa stakeholder yaitu Ketua RT, Ketua RW, kader posyandu, dan Puskesmas. Advokasi kepada pihak ketua RT bertujuan agar pihak RT membantu menggerakkan warga untuk rutin ke posyandu. Advokasi kepada pihak RW bertujuan untuk mengkoordinasikan warga, advokasi kepada kader posyandu bertujuan untuk pendataan ulang balita di wilayah RW 8, membantu pemantauan tumbuh kembang balita, menyebarluaskan informasi mengenai pelaksanaan imunisasi dan jadwal pemberian kapsul vitamin A. Peran kader juga sangat penting dalam optimalisasi gizi pada kelompok balita. (Kosasih et al., 2012) Advokasi kepada pihak Puskesmas Srondol bertujuan untuk membantu dalam pelayanan Posyandu.

\section{Gambar 1. Tim pengabdian menemui} ketua kader RW 8

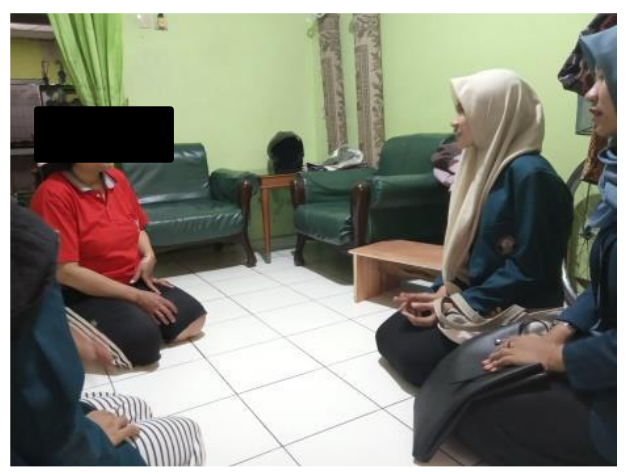

Salah satu tokoh masyarakat yang berperan dalam pelaksanaan program adalah ketua RW lingkungan setempat. Maka, pada kegiatan advokasi dan bina suasana tim pengabdian mepaparkan data hasil observasi berupa jumlah dan nama balita yang mengalami masalah gizi lebih dan stunting serta data tingkat partisipasi balita ke posyandu (D/S) yang rendah pada posyandu bulan November. Selanjutnya dijelaskan mengenai program yang akan dilaksanakan serta meminta ijin dan dukungan dalam pelaksanaan program. Selain itu tim meminta bantuan kepada ketua RW untuk membantu dalam berkoordinasi dengan masing-masing ketua RT untuk meningkatkan partisipasi masyarakat dalam kegiatan posyandu di RW VIII. 


\section{Gambar 2. Advokasi kepada ketua RW 8}

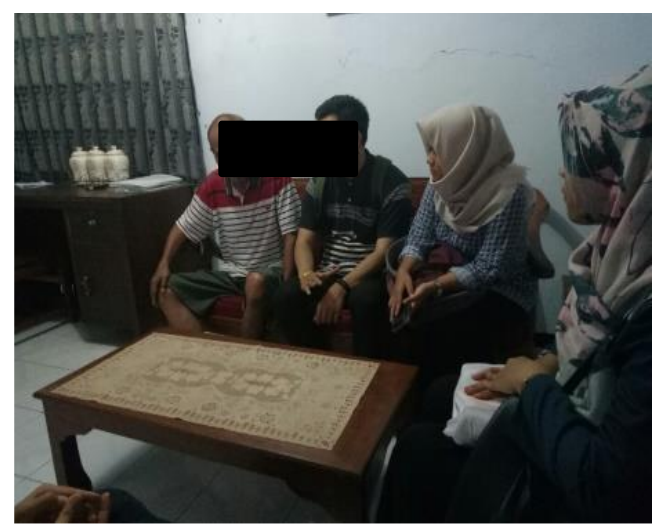

2. Sosialisasi pentingnya posyandu Kegiatan sosialisasi mengenai pentingnya posyandu dilakukan di POS PAUD RW VIII. Hal ini dikarenakan PAUD merupakan tempat berkumpul ibu dan pengasuh balita. PAUD dilakukan selama 2 kali dalam seminggu yaitu pada hari Selasa dan Jumat. Sosialisasi dilakukan pada hari Jumat untuk mengingatkan kembali kepada ibu balita mengenai pentingnya posyandu serta mengingatkan kehadiran di posyandu yang akan dilaksanakan di hari Sabtu. Pada saat sosialisasi ibu diminta untuk menyampaikan kepada tetangga yang punya punya bayi dan balita tentang informasi yang diberikan karena pada saat itu beberapa ibu balita tidak hadir. Setelah sosialisasi, MMT yang digunakan sebagai media presentasi dipasang di depan PAUD karena termasuk lokasi yang strategis, kegiatan ini dilakukan berdasarkan ijin dan persetujuan dari ketua RW dan pihak PAUD.

\section{Edukasi}

Edukasi dilakukan dengan sasaran yaitu ibu bayi dan balita yang mengalami masalah gizi lebih dan stunting. Kegiatan dilakukan pada tanggal 11 Desember 2018. Kegiatan edukasi gizi dalam program SANATA: sayang anak balita ini meliputi materi tentang menu makanan balita, pilihan bahan makanan yang dapat diolah, dan variasi bahan makanan yang dapat dikonsumsi oleh balita.

Metode yang digunakan yaitu dengan door to door atau mengunjungi rumah balita satu per satu. Ibu balita yang diberikan edukasi berjumlah 12 orang. Edukasi yang diberikan kepada ibu balita disesuaikan dengan masalah gizi yang dialami oleh anaknya. Edukasi yang diberikan difokuskan kepada masalah gizi yang dapat terjadi pada balita serta praktik pemberian makan untuk balita yang meliputi jenis, bahan dan pemberian makanan kepada balita baik itu makanan biasa ataupun MP ASI. Media yang digunakan untuk edukasi berupa booklet dengan isi yang informatif serta menarik. Setelah edukasi diberikan maka booklet diberikan kepada ibu balita untuk dibaca.

\section{Gambar 3. Kegiatan edukasi door to door}

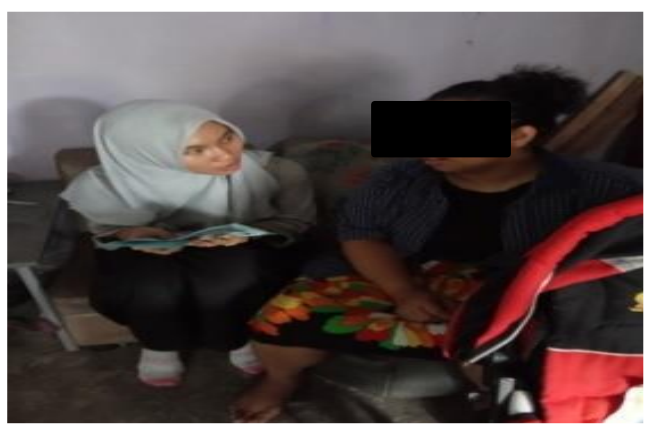

Peranan ibu sangat penting dalam penyediaan makanan bagi anak balitanya, pengetahuan yang diperoleh dari pendidikan baik formal maupun non formal sangat menentukan untuk ditetapkan dalam hal pemilihan dan penentuan jenis makanan yang dikonsumsi oleh balita dan anggota keluarga lainnya.(Yabanc1 et al., 2014) Selain itu, tingkat pendidikan ayah dan ibu secara signifikan berhubungan dengan penurunan risiko kejadian stunting.(Semba et al., 2008; Lee et al., 2012; Schrijner \& Smits, 2018) Edukasi pada ibu balita bertujuan untuk meningkatkan pengetahuan ibu mengenai gizi balita, karena 
sebagaimana hasil penelitian terdahulu menyatakan bahwa ibu dengan pengetahuan gizi yang baik cenderung akan memiliki balita dengan status gizi yang baik dibandingkan ibu dengan pengetahuan gizi yang kurang.(Yabanc1 et al., 2014; Siagian \& Halisitijayani, 2015; Dewi \& Aminah, 2016) Ibu yang memiliki pengetahuan mengenai gizi lebih tidak akan memilih untuk mengkonsumsi makanan yang tinggi kalori dan lemak, namun sebaliknya apabila ibu memiliki pengetahuan yang kurang tentang gizi maka konsumsi makanan tidak sesuai dengan kebutuhan gizi yang diperlukan.

4. Konseling

Program konseling yang diberikan pada program SANATA: Sayang anak balita berupa komunikasi 2 arah secara interpersonal dengan suasana tenang, sehingga ibu menjadi lebih terbuka mengenai penyebab permasalahan gizi anaknya. Kegiatan konseling ini dilakukan dalam 2 kali pertemuan sesuai dengan kesepakatan dengan ibu balita. Pada sesi konseling ini juga ditanyakan mengenai kesanggupan ibu untuk melaksanakan hal yang telah disepakati terkait pemberian makan pada anak balita. Selain itu ibu balita juga dimotivasi untuk menjalankan hal yang telah disepakati dan didiskusikan bersama.

Gambar 4. Kegiatan konseling

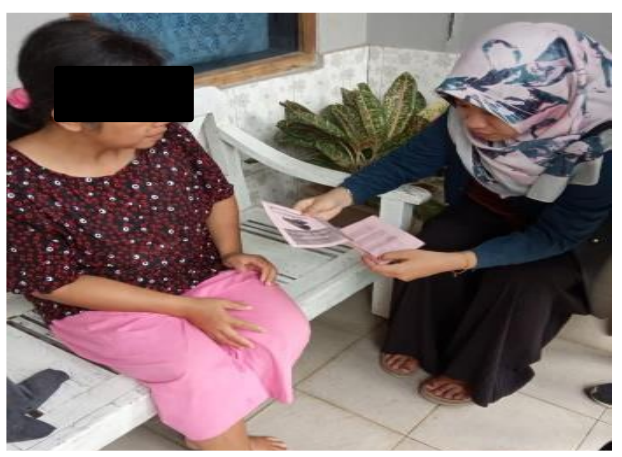

Pengaturan makanan untuk balita salah satunya dengan menentukan jadwal/waktu pemberian makan. Pemberian makan pada balita usia di atas
1 tahun berupa makanan keluarga dengan bumbu yang tidak pedas dan tidak merangsang. Jadwal pemberian makanan tersebut terbagi atas makan utama (pagi, siang, dan malam) serta makanan selingan di antaranya, disertai ASI atau susu 2-3 kali sehari. Pemberian makan pada balita mengikuti pedoman gizi seimbang yaitu dengan memperhatikan jenis dan jumlah zat gizi yang dibutuhkan oleh tubuh, memperhatikan prinsip keanekaragaman pangan, aktifitas fisik, perilaku hidup bersih, dan mempertahankan berat badan.(Asosiasi Dietisien Indonesia (ASDI) et al., 2014)

5. Monitoring dan evaluasi (monev) program

Dilaksanakan selama berlangsungnya program hingga satu minggu berikutnya untuk mengetahui dampak program pasca dilaksanakan. Monitoring dan evaluasi dilaksanakan dengan cara observasi (pengamatan), wawancara, pengukuran status gizi dengan pengukuran antropometri $\mathrm{BB} / \mathrm{TB}$ dan evaluasi asupan makan balita dengan form recall 1 kali 24 jam.

Tabel 1. Tahapan monitoring dan evaluasi proses, output (hasil), dan outcome (dampak)

\begin{tabular}{|c|c|c|c|}
\hline & Monev Proses & Monev Hasil & \begin{tabular}{|l|l|} 
Monev Dampak \\
\end{tabular} \\
\hline Advokasi & $\begin{array}{ll}\text { Tokoh } \\
\text { masyarakat } \\
\text { berhasil diajak } \\
\text { diskusi dan } \\
\text { terjalan } \\
\text { komunikasi 2 } \\
\text { arah }\end{array}$ & $\begin{array}{ll}\text { Tokoh } \\
\text { masyarakat mau } \\
\text { untuk } \\
\text { menyebarkan } \\
\text { informasi secara } \\
\text { lebih merata }\end{array}$ & \begin{tabular}{|l|} 
Jumlah balita \\
yang datang ke \\
posyandu \\
meningkat
\end{tabular} \\
\hline Konseling & $\begin{array}{ll}\text { Ada feedback } \\
\text { dari ibu atau } \\
\text { pengasuh } \\
\text { berupa } \\
\text { pertanyaan } \\
\text { ataunun } \\
\text { respon yang } \\
\text { lain } \\
\end{array}$ & $\begin{array}{l}\text { - Perubahan pola } \\
\text { makan balita } \\
\text { hingga dapat } \\
\text { mencapai } \\
\text { kecukupan } \\
>80 \% \text { zat gizi } \\
\text { makro. }\end{array}$ & $\begin{array}{ll} & \text { Terjadi } \\
\text { peningkatan } \\
\text { variasi asupan } \\
\text { makan balita } \\
\text { - } \\
\text { Terjadi } \\
\text { peningkatan } \\
\text { status gizi anak }\end{array}$ \\
\hline Edukasi & $\begin{array}{ll}\text { Ada feedback } \\
\text { dari pengasuh }\end{array}$ & $\begin{array}{l}\text { Peningkatan } \\
\text { pengetahuan ibu } \\
\text { terhadap MP- } \\
\text { ASI dan } \\
\text { pemberian } \\
\text { makan balita }\end{array}$ & $\begin{array}{l}\text { Terjadi peningkatan } \\
\text { variasi makanan balita }\end{array}$ \\
\hline Sosialisasi & $\begin{array}{ll}\text { Sosialisasi } \\
\text { dihadiri oleh } \\
\text { minimal } 40 \\
\text { ibuppengasuh } \\
\text { balita } \\
\text { - Ada feedback } \\
\text { dabi } \\
\text { ibupengasuh } \\
\text { balita }\end{array}$ & $\begin{array}{l}\text { Warga paham } \\
\text { pentingnya } \\
\text { pelaksanaan } \\
\text { posyandus } \\
\text { Warga tahu } \\
\text { manfaat dan } \\
\text { kerugian jika } \\
\text { tidak ke } \\
\text { posyandu }\end{array}$ & $\begin{array}{l}\text { Terjadi peningkatan } \\
\text { balita yang datang ke } \\
\text { posyandu (D/S } \\
\text { meningkat) }\end{array}$ \\
\hline
\end{tabular}




\section{Kesimpulan dan Saran}

Telah terbentuk kesepakatan antara tim pengabdian dengan pihak RW 08 Kelurahan Srondol Kulon untuk pelaksanaan program SANATA: Sayang Anak Balita di wilayah Posyandu RW 08 Kel. Srondol Kulon sebelum program dimulai. Tokoh masyarakat bersedia berpartisipasi langsung dalam program (memberikan perijinan dan membantu menyebarluaskan informasi terkait jadwal posyandu). Tingkat atau angka partisipasi posyandu (cakupan D/S) mengalami kenaikan dimana pada bulan sebelumnya D/S posyandu Mawar RW 08 Kelurahan Srondol Kulon berada pada angka 32,5\% menjadi 37,1 \% pada bulan berikutnya. Akan tetapi, angka partisipasi ini masih tergolong rendah sehingga perlu dilakukan upaya-upaya lain untuk meningkatkan partisipasi ke posyandu.

Terdapat peningkatan pengetahuan ibu tentang MP-ASI dan pemberian makan pada balita, dan peningkatan pola asuh ibu balita dalam pemberian makan balita sesuai kebutuhan setelah dilakukan program. Asupan zat gizi pada balita yang dilihat dari perubahan pola makan balita dapat mencapai kecukupan $80-110 \%$ zat gizi makro dengan rincian sebagai berikut: tingkat kecukupan energi tercapai pada 4 dari 10 balita, tingkat kecukupan protein tercapai pada 4 dari 10 balita, tingkat kecukupan lemak tercapai pada 4 dari 10 balita, dan tingkat kecukupan karbohidrat tercapai pada 6 dari 10 balita. Tidak terjadi penurunan status gizi $\mathrm{BB} / \mathrm{TB}$ (pada 10 balita) dan terjadi peningkatan status gizi $\mathrm{BB} / \mathrm{TB}$ pada 5 dari 10 balita.

Untuk menjaga keberlanjutan program, sebaiknya ada pengkayaan materi (update pengetahuan) pada ibu balita secara berkala. Penghargaan/reward/apresiasi dari pihak $\mathrm{RW} /$ posyandu bagi ibu yang memiliki balita berstatus gizi baik, memiliki pengetahuan gizi yang baik, serta mampu melaksanakan pola pengasuhan dan pemberian makan yang baik bagi balita akan lebih menyemangati para ibu balita dalam mengoptimalkan gizi balitanya.

\section{DAFTAR PUSTAKA}

Abeway S, Gebremichael B, Murugan R, Assefa M \& Adinew YM, 2018. Stunting and its determinants among children aged 6-59 Months in Northern Ethiopia: A cross-sectional study. Journal of Nutrition and Metabolism, 2018.

Asosiasi Dietisien Indonesia (ASDI), Ikatan Dokter Anak Indonesia (IDAI) \& Persatuan Ahli Gizi Indonesia (PERSAGI), 2014. Penuntun diet anak. 3rd ed., Badan Penerbit FKUI.

Bhutta ZA, Ahmed T, Black RE, Cousens S, Dewey K, Giugliani E, et al., 2008. What works? Interventions for maternal and child undernutrition and survival. The Lancet, 371, pp.471-440.

Dewi M \& Aminah M, 2016. Pengaruh Edukasi Gizi terhadap Feeding Practice Ibu Balita Stunting Usia 624 Bulan (The Effect of Nutritional Knowledge on Feeding Practice of Mothers Having Stunting Toddler Aged 6-24 Months). Indonesian Journal of Human Nutrition, 3(1), pp.1-8.

Dewi R \& Anisa R, 2018. The Influence of Posyandu Cadres Credibility on Community Participation in Health Program Pengaruh Kredibilitas Kader Posyandu terhadap Partisipasi Masyarakat pada Program Kesehatan. The Messenger, 10(1), pp.83-92.

Kementerian kesehatan, 2011. Pedoman Umum Pengelolaan posyandu,

Kementerian Kesehatan, 2018. Riset Kesehatan Dasar 2018. 
Kosasih C., W R \& T S, 2012. The empowering of cadres and the family mentoring in preventing nutrition disorders at pakuwon village and sindangsari sub-district, cisurupan regency, garut. Jurnal Aplikasi Ipteks untuk Masyarakat, 1(1), pp.6-12.

Lee J, Houser RF, Must A, De Fulladolsa PP \& Bermudez OI, 2012. Socioeconomic disparities and the familial coexistence of child stunting and maternal overweight in guatemala. Economics and Human Biology, 10(3), pp.232-241. Available at: http://dx.doi.org/10.1016/j.ehb.2011 .08 .002 .

Schrijner S \& Smits J, 2018. Grandparents and Children's stunting in sub-Saharan Africa. Social Science and Medicine, 205(October 2017), pp.90-98. Available at: https://doi.org/10.1016/j.socscimed. 2018.03.037.

Semba RD, de Pee S, Sun K, Sari M, Akhter N \& Bloem MW, 2008. Effect of parental formal education on risk of child stunting in Indonesia and Bangladesh: a cross-sectional study. The Lancet, 371(9609), pp.322-328.

Siagian CM \& Halisitijayani M, 2015. Mother's Knowledge On Balanced Nutrition to Nutritional Status of Children in Puskesmas (Public Health Center) In the District of Pancoran, Southern Jakarta 2014. International Journal of Current Microbiology and Applied Studies, 4(7), pp.815-826.

Tumilowicz A, Beal T \& Neufeld LM, 2018. A review of child stunting determinants in Indonesia., (March), pp.1-10.

UNICEF, WHO \& World Bank, 2018. LEVELS AND TRENDS IN CHILD MALNUTRITION,

Yabancı N, Kısaç İ \& Karakuş SŞ, 2014. The Effects of Mother's Nutritional Knowledge on Attitudes and Behaviors of Children about Nutrition. Procedia - Social and Behavioral Sciences, 116, pp.44774481. 